Marwah: Jurnal Perempuan, Agama dan Jender (p-ISSN: 1412-6095|e-ISSN: 2407-1587)

Vol. 17, No. 1, 2018, Hal. 80 - 95

\title{
PENERAPAN KESETARAAN GENDER DALAM PENGEMBANGAN KARIR KARYAWAN \\ (Studi Perbandingan Antara Bank Syariah dan Konvensional di Pekanbaru)
}

\author{
AINUN MARDIAH \\ UIN Sultan Syarif Kasim Riau, Indonesia \\ ainun.mardiab@uin-suska.ac.id \\ ZULHAIDA \\ UIN Sultan Syarif Kasim Riau, Indonesia \\ zulbaida@uin-suska.ac.id
}

\begin{abstract}
This article aims to determine the application of gender equality in the implementation of Islamic and conventional bank employee career development in the city of Pekanbaru and to find out the differences in gender equality in the implementation of employee career development between Islamic and conventional banks in the city of Pekanbaru. The number of samples in this study was 100 respondents. Data analysis used gender analysis of SWOT and Oneway ANOV A models. Based on the results of the study it was found that there was no gender gap in the implementation of banking employee career development in Pekanbaru. It means that various indicators in career development in this study did not distinguish opportunities for career development for both male and female employees. Based on the One Way ANOVA test known that there are no gender differences in terms of career development between conventional banking and Islamic banks.
\end{abstract}

Keywords: Career development, gender, employees

\section{ABSTRAK}

Artikel ini bertujuan untuk mengetahui penerapan kesetaraan gender dalam pelaksanaan pengembangan karir karyawan bank syariah dan konvensional di Kota Pekanbaru dan untuk mengetabui perbedaan kesetaraan gender dalam pelaksanaan pengembangan karir karyawan antara bank syariah dan konvensional di Kota Pekanbaru. Jumlah sampel dalam penelitian ini adalah berjumlah 100 orang responden. Analisis data menggunakan analisis gender model SWOT dan Oneway ANOVA. Berdasarkan basil penelitian diketahui bahwa tidak terdapat kesenjangan gender dalam penerapan pengembangan karir karyawan perbankan di Pekanbaru. Artinya babwa berbagai indikator dalam pengembangan karir pada penelitian ini tidak membedakan kesempatan untuk memperoleb pengembangan karir baik bagi karyawan laki-laki maupun perempuan.Berdasarkan uji One Way ANOV A diketabui babwa tidak terdapat perbedaan gender dalam hal pengembangan karir antara perbankan konvensional dengan bank syariah.

Kata Kunci: Pengembangan karir, gender, karyawan 


\section{A. PENDAHULUAN}

Penerapan kesetaraan gender telah dilakukan pemerintah dengan mengikuti pertemuan beberapa negara dan menghasilkan program tujuan pembangunan millenium (MDGs-Millenium Development Goals) dimana prioritas ke-3 dari tujuan pembangunan millenium itu adalah kesetaraan gender. Namun meskipun begitu perjuangan perempuan untuk mendapatkan kesetaraan gender masih menghadapi banyak kendala.

Menurut laporan pembangunan manusia 2015 yang dipublikasikan UNDP GDI Indonesia berada pada peringkat ke-110 dibandingkan dari 187 negara yang memiliki angka GDI. Tetapi pada tahun 2016, peringkat itu tidak mengalami perubahan, tetap peringkat ke-110 yang berarti perempuan Indonesia masih kurang tertarik dengan kesamaan hak sosial dengan laki-laki. Tidak mudah bagi perempuan bekerja untuk mencapai karier yang tinggi. Ada banyak tahapan, kesempatan atau bahkan hambatan bagi perempuan untuk mencapai kesuksesan dalam karier.Rowley (2013) dalam penelitiannya menemukan bukti yang nyata bahwa pengalaman kerja, pelatihan dan pengembangan, budaya dominasi laki-laki, mentoring, maskulinitas dan konflik pekerjaa-keluarga merupakan beberapa faktor yang mempengaruhi sukses karier perempuan.

Dalam dunia kerja, sering perempuan menempati posisi tidak penting.Secaratradisional perempuan diharapkan berada di rumah mengerjakan pekerjaandomestik seperti memasak,merawat anak, membersihkan dan mengurus serta menata rumah.Sementara laki-lakibekerja mencari nafkah.Keikutsertaan perempuan dalam bekerjasama dengan kaumlaki-laki menimbulkan peran ganda wanita(Sriewijono, dkk, 2006). Perempuan yang memiliki motivasi tinggi untuk memperoleh jabatan, tantangan dalam pekerjaan,bersedia untuk bekerja keras demi mencapai tujuanmerupakan indikator darimaskulinitas yang memberikan pengaruh positif pada sukses karier. Kemudian bagi perusahaan, proses dan pengembangan karir dilakukan melalui pembinaan karyawan kearah the right man on the right place.Faktor pendidikan, training dan pengembangan merupakan faktor yang dapat meningkatkan pengetahuan dan keahlian individu.

Di Indonesia, Tingkat Partisipasi Angkatan Kerja (TPAK) laki-laki jauh lebih tinggi dibandingkan dengan TPAK perempuan. Gambaran tersebut terlihat pada keadaan Agustus 2015, Februari 2016, dan Agustus 2016, dimana TPAK laki-laki sekitar 1,5kali TPAK perempuan. Sebagai contoh, pada Agustus 2016 TPAK laki-laki mencapai 81,97 persen sementara pada perempuan hanya 50,77 persen. Hal tersebut dapat diartikan 
bahwa dari 100 orang penduduk usia kerja laki-laki, yang termasuk angkatan kerja sekitar 82orang, sementara pada perempuan dari 100 orang penduduk usia kerja perempuan, hanya sekitar 51orang yang termasuk angkatan kerja. (BPS, 2016).

Berdasarkan perbedaan jenis kelamin, Agustus 2016 menunjukkan bahwa sektor formal masih didominasi kaum laki-laki, yangmencapai 63,78 persen (hampir dua pertiga bagian), sedangkan pada Agustus 2015 dan Februari 2016masing-masing mencapai 65,71 persen dan 63,41 persen. Sementara pada sektor informal kaum laki-laki juga mendominasi tetapi dengan perbedaan yang tidak terlalu besar. Pada Agustus 2016persentase penduduk informal yang berjenis kelamin laki-laki sebanyak 59,49 persen sedangkan perempuan sebesar 40,51 persen.Jadi terlihat bahwa jenjang karirperempuan di sektor formal maupun informal tidaksecepat bagi kaum laki-laki. Perlu untuk dipahami oleh semua pihak bahwa dalam pelaksanaan pengembangan karir, penerapan kesetaraan gender dibutuhkan dalam hal peningkatan karir dan termasuk juga tentang pentingnya kesetaraan dalam kehidupan sehari-hari baik itu di dunia kerja, keluarga dan kehidupan bermasyarakat. Di Kota Pekanbaru, saat iniberoperasi 315 bank yang terdiri dari 6 Jenis bankyaitu, Bank Umum Pemerintah, BankPembangunan Daerah, Bank Umum SwastaNasional, Bank Umum Syariah, BankPerkreditan Rakyat Syariah, dan BankPerkreditan Rakyat konvensional (BPS, 2015).

Berdasarkan permasalahan yang dikemukakan di atas, maka peneliti merasa mengkaji dan meneliti tentang bagaimana penerapan kesetaraan gender dalam pelaksanaan pengembangan karir karyawan bank di Kota Pekanbaru.Apakah terdapat perbedaan penerapan kesetaraan gender dalam pelaksanaan pengembangan karir karyawan bank syariah dan konvensional di Kota Pekanbaru. Perumusan masalah dalam penelitian ini adalah Bagaimana penerapan kesetaraan gender dalam pelaksanaan pengembangan karir karyawan bank syariah dan konvensional di Kota Pekanbaru (berdasarkan analisis model SWOT). apakah terdapat perbedaan kesetaraan gender dalam pelaksanaan pengembangan karir karyawan antara bank syariah dan konvensional di Kota Pekanbaru. Tujuan penelitian adalah Untuk mengetahui penerapan kesetaraan gender dalam pelaksanaan pengembangan karir karyawan bank syariah dan konvensional di Kota Pekanbaru (berdasarkan analisis model SWOT).untuk mengetahui perbedaan kesetaraan gender dalam pelaksanaan pengembangan karir karyawan antara bank syariah dan konvensional di Kota Pekanbaru. 


\section{B. TINJAUAN PUSTAKA}

\section{Penerapan Kesetaraan Gender}

Gender merupakan perbedaan yang terlihat antara laki-laki dan perempuanberdasarkan nilainya (Marmawi, 2009).Nilai disini berkaitan dengan peran yang diaktualisasikan dalam masyarakat.Misalnya, perempuanbiasanya menjadi seorang istri dan ibu rumah tangga, sedangkan laki-laki bekerja diluar untukmencari nafkah. Sedangkan kesetaraan dan keadilan gender adalah suatu kondisi dimana porsi dan siklus sosial perempuan dan laki-laki setara, seimbang dan harmonis. Kondisi ini dapat terwujud apabila terdapat perlakuan adil antara perempuan dan laki-laki. Penerapan kesetaraan dan keadilan gender harus memperhatikanmasalah kontekstual dan situasional, bukan berdasarkan perhitungan secarasistematis dan tidak bersifat universal. Bentuk-bentuk ketidakadilan gender antara lain(Simatauw et al. 2001) adalah marjinalisasi (peminggiran) ekonomi, subordinasi (penomorduaan), beban kerja berlebih (over burden), cap-cap negatif (stereotype), kekerasan (violence).

Kata gender berasal dari bahasa Inggris berarti “jenis kelamin”.Gender adalah perbedaan yang tampak antara laki-laki dan perempuan dilihat dari sifat dan tingkah laku yang dikonstruksi secara sosial maupun kultural. Gender menurut Inpres Nomor 9 Tahun2000 tentang PedomanPengarusutamaan Gender dalam Pembangunan Nasionaladalah konsep yangmengacu pada pembedaan peran dan tanggung jawabperempuan dan laki-laki yang terjadi akibatdari dan dapat berubah oleh keadaan sosial dan budaya masyarakat. Gender menurut Daulay (2007) diartikan sebagai pembedaan peran, perilaku, perangai laki-laki dan perempuan oleh budaya/masyarakat melalui interpretasi terhadap perbedaan biologis laki-laki dan perempuan.

Menurut Fakih (2008) konsep gender adalah semua hal yang dapat dipertukarkan antara sifatperempuan dan laki-laki, yang bisa berubah dari waktu ke waktu sertaberbeda dari tempat ke tempat lainnya, maupun berbeda dari suatu kelas kekelas lain. Gender menurut Hubeis (2010) adalah suatu konsep yang merujuk pada suatusistem peranan dan hubungan antaraperempuan dan laki-laki yang tidak ditentukanoleh perbedaan biologis, akan tetapi olehlingkungan sosial-budaya, politik, dan ekonomisehingga tidak bersifat kodrati atau mutlak. Menurut Simatauw et al. (2001) gender dan jenis kelamin(sex) memiliki konsep yang berbeda. Gender merupakanbentukan manusia yang tidak mutlakdan dapat berubahtergantung situasi, kondisi, dan waktu, serta dipengaruhioleh budaya dan kehidupan sosial, seperti 
perempuanmemasak, mengurus rumahtangga, mengurus anak, dankegiatan lainnya.Sedangkan jenis kelamin (sex)merupakan sesuatu yang bersifat kodrat yang tidak dapatdiubah, sepertiperempuan menstruasi, hamil, menyusui,dan ciri-ciri biologis perempuan lainnya.Laki-lakimenghamili, memiliki sperma, dan ciri-ciri biologislainnya.

Menurut Sarah Byrne and Matthias Schnyder (2005), menyatakan gender gender bukan "seks" (misalnya, perbedaan biologis antara laki-laki dan perempuan) dan gender bukanlah sesuatu yang secara eksklusif tentang perempuan.Sebaliknya, gender adalah defenisi dari segi sosial antara perempuan dan laki-laki. Dengan demikian perspektif gender mempertimbangkan peran lakilaki dan perempuan dibedakan pada kekuasaan dalam masyarakat.

\section{Teknik Analisis Gender Model SWOT}

Analisis gender merupakan langkah awal dalam rangka penyusunan kebijakan program dan kegiatan yang responsif gender. Analisis gender memerlukan data gender, yaitu data kuantitatif maupun kualitatif yang sudah terpilah antara laki-laki dan perempuan. Data gender ini kemudian disusun menjadi indikator gender. Teknik analisis gender yang digunakan dalam penelitianini adalah (UNFPA, Kantor Meneg PP.RI, 2001) adalah Model Harvard, Mosser, SWOT, Model Gender Analysis Pathway atau GAP. Teknik analisis gender model SWOT merupakan suatu analisis manajemen dengan cara mengidentifikasi secara internal mengenai kekuatan dan kelemahan dan secara eksternal mengenai peluang dan ancaman. Aspek nternal dan Eksternal tersebut dipertimbangkan dalam kaitan dengan konsep strategis dalam rangka menyusun program aksi, langkah-langkah/tindakan untuk mencapai sasaran maupun tujuan kegiatan dengan cara memaksimalkan kekuatan dan peluang, serta meminimalkan kelemahan dan ancaman sehingga dapat mengurangi resiko dan dapat meningkakan efektivitas dan efisiensi pelaksanaan.

\section{Pengembangan Karir Karyawan}

Guy menyebutkan tiga faktor determinan dalam pengembangan karierperempuan di organisasi publik yakni kesempatan,kekuasaan, dan jumlah(proporsi). Tinggi rendahnya kesempatan, besar kecilnya kekuasaan dan jumlahperwakilan (representasi) akan berpengaruh terhadap administrasi negara danimplementasi program. Kehidupan wanita karir menunjukkanseberapa besar manfaat perempuan sebagaipekerja mampu memenuhi kebutuhannya secara individu, bagi rumahtangganya maupunmasyarakat. Banyak perempuan yang berkarir 
mengalami beberapa kehidupan yang tidaksesuai dengan apa yang diharapkan dalamruang lingkup pekerjaannya. Sehingga dapatmembuat seseorang merasa tertekan dansecara potensial mempengaruhi sikap merekaterhadap pengembangan karir.

Pengembangan karir menurut Stone (dalamKadarisman, 2013) adalah "proses dan kegiatan mempersiapkan seorangkaryawan untuk menduduki jabatan dalam organisasi atau perusahaan, yang akandilakukan di masa mendatang".Pengembangan tersebut mencakup pengertianbahwa manajer SDM telah menyusun perencanaan sebelumnya tentang cara-carayang perlu dilakukan untuk mengembangkan karier karyawan selama ia bekerja. Sedangkan pengertiann karir menurut Handoko (dalam Kadarisman, 2013) adalah pengembangan karir merupakan upaya-upaya pribadi seorang karyawan untuk mencapai suatu rencana karir. Pengembangan karir seorang karyawan dilhat dari prestasi kerjanya. Tanpa prestasi kerja yang memuaskan, maka akan sulit bagi seorang karyawan untuk dipromosikan ke pekerjaan atau jabatan yang lebih tinggi di masa depan.

Menurut Moekijat (2010) pada dasarnya pengembangan karir dapat bermanfaat bagi perusahaan maupun pegawai. Bagi perusahaan, pengembangan karir dapatmenyesuaikan kemampuan pegawai dengan strategi, meningkatkan supply internal pegawai, menyiapkan penempatan internasional, memampukan pegawai untuk bekerja dengan pegawai yang berbeda latar belakangnya, mengurangi perputaran kerja, menyalurkan pegawai yang berpotensi, mendorong untuk meningkatkan kemampuan, mengurangi penumpukan karyawan, memuaskan kebutuhan pegawai, mengurangi atau menghilangkan terjadinya diskriminasi. Bagi pegawai, pengembangan karir identik dengan keberhasilan, karena pengembangan karir bermanfaat untuk dapat menggunakan potensi seseorang dengan sepenuhnya, menambah tantangan dalam bekerja, meningkatkan otonomi, meningkatkan tanggung jawab.

Menurut Meilan Sugiarto (2012) mendefenisikan kesuksesan proses pengembangan karir tidak hanya penting bagi organisasi secara keseluruhan. Dalam hal ini beberapa faktor yang berpengaruh pada pengembangan karir meliputi hubungan pegawai dan organisasi, personalitas pegawai, faktor-faktor eksternal, politicking dalam organisasi, sistem penghargaan, jumlah karyawan, ukuran organisasi, kultur organisasi. Menurut Kadarisman (2012), dalam pengembangan karir harus mencari informasi tentang pengetahuan dan kemampuan yang diperlukan perusahaan, sistem promosi apa yang berlaku, bila ada syarat tertentu harus mengikuti pelatihan. Apakah pelatihan 
tersebut di adakan oleh perusahaan atau yang bersangkutan sendiri yang mencari kesempatan dan peluang tersebut, faktor keberuntungan berperan atau tidak dalam pengembangan karir.

Penelitian yang berhubungan dengan pengembangan karir karyawan telah banyak diteliti sebelumnya, berikut sebagian yang melakukan penelitian tersebut.Afolabi, dkk (2008) sebelumnya pernah melakukan penelitianuntuk membuktikanadanya pengaruh antara gender dan gaya kepemimpinan terhadapkarir komitmen.Disamping itu Rahayu (2012) pernah melakukan penelitian untuk mengetahuiadanya hubungan antara genderdan gaya kepemimpinan terhadap karirkomitmen. Kedua hasil penelitian menunjukkan hasil yang berbeda.Dalam afolabi (2008) gender dan gaya kepemimpinan berpengaruh secara signifikanterhadap karir komitmen,sedangkan penelitian yang dilakukan Rahayu (2012), menemukan hasil yang berbeda, Rahayu dalam penelitiannya mngatakan bahwa tidak ada hubungan nya antara gender dan gaya kepemimpinan terhadap karirkomitmen.Artinya, karir komitmen seseorang tidak dipengaruhi oleh gender,karena dalam penelitiannya karir komitmenyang rendah atau tinggi dipengaruhioleh diri seseorang itu sendiri bukan dari gendernya. Berdasarkan uraianuraian diatas, penelitian ini akan mengukur gender dan gaya kepemimpinan terhadapkarir komitmen darikaryawan rumah sakit Bumi Waras Bandar Lampung secarakeseluruhan berdasarkan jenis kelamin, tingkatpendidikan dan lama nya masa kerja.

Penelitian Penny Rahmawaty (2008) yang menemukan bahwa kedudukan kaum perempuan di instansi pemerintah lebih banyak berada pada tingkat administratif dan hanya sedikit sebagai pengambil kebijakan. Mereka yang mencapai level kepangkatan golongan IV masih terbatas. Partisipasi kaum perempuan di dunia kerja juga masih lebih kecil dibandingkan laki-laki.Kaum perempuan lebih banyak bekerja di sektor jasa kemasyarakatan dan sektor perdagangan.

Penelitian ini akan menganalisis penerapan kesetaraan gender dalam pengembangan karir karyawan bank dengan menggunakan analisis gender model SWOT (menganalisis kekuatan, kelamahan, kesempatan dan hambatan apa yang dimiliki oleh laki-laki dan perempuan dalam pengembangan karir). Kemudian selanjutnya penelitian ini juga akan menganalisis perbedaan penerapan kesetaraan gender dalam pengembangan karir karyawan bank syariah dan karyawan bank konvensional. 


\section{METODE PENELITIAN}

Penelitian dilakukan di Pekanbaru. Objek yang diteliti adalah karyawan bank syariah dan bank konvensional.Jenis dan sumber data penelitian ini terdiri dari data primer yaitu data yang berhubungan dengan tanggapan responden mengenai pengembangan karir karyawan dan data yang berhubungan dengan karakteristik responden. Sumber data dalam penelitian ini adalahkaryawan bank syariah dan konvensional di Pekanbaru. Data sekunder yaitu data pendukung yang berhubungan dengan kajian penelitian. Pada pendekatan kualitatif pemilihan responden didasarkan pada kualitas karena ketepatan dalam memilih responden merupakan salah satu kunci keberhasilan penelitian kualitatif.

Populasi yang akan digunakan dalam penelitia ini adalah seluruh karyawan bank syariah dan konvensional di Pekanbaru. Sampel dalam penelitian ini adalah karyawan bank syariah dan konvensional di Pekanbaru. Penentuan sampel pada penelitian ini menggunakan teknik simplerandom sampling. Dikatakan simple (sederhana) karena pengambilan anggota populasi dilakukan secara acak tanpa memperhatikan strata yang ada dalam populasi itu. Cara demikian dilakukan bila anggota populasi dianggap homogen (Sugiono, 2003). Generalisasi dari penelitian populasi ini adalah kepada seluruh karyawan bank lain yang memiliki karakteristik yang sama dengan subyek dalam penelitian ini. Pengumpulan data dilakukan denganwawancaradan kuesioner. Variable dalam penelitian adalah kesetaraan gender dan pengembangan karir. Penelitian ini menggunakan analisis data kualitatif dan kuantitatif yaitu menggunakan Analisis Gender Model SWOT dan One Way $A N O V A$.

\section{HASIL DAN PEMBAHASAN}

Analisis deskriptif dimaksudkan untuk mendapatkan gambaran / deskripsi mengenai tanggapan dari responden mengenai variabel pengembangan karir karyawan yang terdapat dalam penelitian.Hasil penelitian dari pernyataan yang diajukan untuk mengukur variabel pengembangan karir karyawan pada bank syariah dan bank konvensional di Kota Pekanbarudiketahui bahwa perusahaan telah memberikan pola atau formulasi pengembangan karir yang jelas dan bagus bagi karyawan, dapat dilihat dari rentang skala yang tinggi yaitu sebesar 424.Kemudian sebagian besar hasil tanggapan responden menyatakan sangat setuju bahwa perusahaan memberikan pola atau formulasi pengembangan karir yang jelas bagi karyawan, yaitu sebanyak 45 orang responden. 
Selanjutnya untuk pernyataan mengenai perusahaan menyediakan rencana karir karyawan diketahui bahwa perusahaan telah menyediakan rencana karir yang bagus bagi karyawan, dapat dilihat dari rentang skala yang tinggi yaitu sebesar 432.Kemudian sebagian besar hasil tanggapan responden menyatakan sangat setuju bahwa perusahaan menyediakan rencana karir karyawan, yaitu sebanyak 49 orang responden. Untuk pernyataan mengenai perusahaan memberikan penghargaan bagi karyawan diketahui bahwa perusahaan memberikan penghargaan bagi karyawan, dapat dilihat dari rentang skala yang tinggi yaitu sebesar 445.Kemudian sebagian besar hasil tanggapan responden menyatakan sangat setuju bahwa perusahaan memberikan penghargaan bagi karyawan, yaitu sebanyak 57 orang responden.

Selanjutnya untuk pernyataan mengenai perusahaan memberikan pelatihan yang dapat menunjang pengembangan karir karyawan diketahui bahwa perusahaan telah memberikan pelatihan yang dapat menunjang pengembangan karir karyawan, dapat dilihat dari rentang skala yang tinggi yaitu sebesar 447.Kemudian sebagian besar hasil tanggapan responden menyatakan sangat setuju bahwa perusahaan memberikan pelatihan yang dapat menunjang pengembangan karir karyawan, yaitu sebanyak 54 orang responden. Untuk pernyataan mengenai perusahaan memberikan memberikan prosedur yang jelas dalam pengangkatan, promosi dan masalah pemberhentian / pensiun karyawan diketahui bahwa perusahaan memberikan memberikan prosedur yang jelas dalam pengangkatan, promosi dan masalah pemberhentian / pensiun karyawan, dapat dilihat dari rentang skala yang tinggi yaitu sebesar 468. Kemudian sebagian besar hasil tanggapan responden menyatakan sangat setuju bahwa perusahaan memberikan memberikan prosedur yang jelas dalam pengangkatan, promosi dan masalah pemberhentian / pensiun karyawan, yaitu sebanyak 68 orang responden.

Untuk pernyataan mengenai perusahaan mengkomunikasi kesempatan berkarir kepada karyawan dengan jelas diketahui bahwa perusahaan mengkomunikasi kesempatan berkarir kepada karyawan dengan jelas, dapat dilihat dari rentang skala yang tinggi yaitu sebesar 454.Kemudian sebagian besar hasil tanggapan responden menyatakan sangat setuju bahwa perusahaan mengkomunikasi kesempatan berkarir kepada karyawan dengan jelas, yaitu sebanyak 59 orang responden. Untuk pernyataan mengenai promosi jabatan dilakukan berdasarkan penilaian kinerja karyawan diketahui bahwa promosi jabatan dilakukan berdasarkan penilaian kinerja karyawan, dapat dilihat dari rentang skala yang tinggi yaitu sebesar 429.Kemudian sebagian besar hasil tanggapan responden menyatakan 
sangat setuju bahwa promosi jabatan dilakukan berdasarkan penilaian kinerja karyawan, yaitu sebanyak 45 orang responden. Untuk pernyataan mengenai perusahaan menyediakan data mengenai pola pergantian tempat (pergantian posisi karyawan) yang tepat bagi karyawan diketahui bahwa perusahaan menyediakan data mengenai pola pergantian tempat (pergantian posisi karyawan) yang tepat bagi karyawan, dapat dilihat dari rentang skala yang tinggi yaitu sebesar 459.Kemudian sebagian besar hasil tanggapan responden menyatakan sangat setuju bahwa perusahaan menyediakan data mengenai pola pergantian tempat (pergantian posisi karyawan) yang tepat bagi karyawan, yaitu sebanyak 64 orang responden.

Kesetaraan gender merupakan tujuan nasional dan internasional. Tujuan dari diberlakukannya kesetaraan gender ini adalah untuk terwujudnya keadilan dan kesetaraan yaitu suatu keadaan dimana laki-laki dan perempuan memiliki kesempatan yang sama untuk mengakses segala bidang pekerjaan.Indikator pengembangan karir meliputi prestasi kerja, kesetiaan pada organisasi, mentor dan sponsor, dukungan para bawahan, kesempatan untuk bertumbuh, daya kompetitif. Penerapan kesetaraan gender dalam pelaksanaan pengembangan karir karyawan bank syariah dan bank konvensional dianalisis dengan menggunakan Model SWOT, yaitu dengan cara mengidentifikasi kekuatan, kelemahan, peluang dan ancaman atau hambatan dalam pengembangan karir karyawan bank syariah dan bank konvensional yang dilihat dalam perspektif gender.

Berdasarkan hasil penelitian maka dapat diidentifikasi beberapa kekuatan dalam hal pengembangan karir karyawan, yaitu setiap karyawan laki-laki maupun perempuan memiliki latar belakang dan tingkat pendidikan terakhir yang mendukung.Karyawan memenuhi persyaratan untuk pengembangan karir. Apabila seluruh persyaratan untuk pengembangan karir telah terpenuhi, maka baik karyawan laki-laki maupun karyawan perempuan sama-sama memiliki kesempatan yang sama untuk mengikuti pengembangan karir. Hal ini dapat menjadi kekuatan bagi karyawan untuk dapat mengembangkan karirnya. Selanjutnya beberapa kelemahan yang dapat diidentifikasi dari hasil penelitian adalah bagi karyawan perempuan ada yang merasa kesulitan menyakinkan suami untuk meningkatkan karir di perbankan karena pertimbangan keluarga dan pekerjaan.Karyawan merasa cepat merasa puas dengan hasil yang dicapai sekarang. Hal ini dapat menjadi salah satu penghambat dalam pengembangan karir perempuan di perbankan.

Kemudian beberapa peluang dalam hal pengembangan karir karyawan, yaitu UU No. 13 tahun 2003 tentang ketenagakerjaan.Undang-undang ini menjelaskan tentang 
beberapa hal yang berkaitan tentang ketenagakerjaan, mulai dari kesempatan dan perlakuan yang sama; perencanaan tenaga kerja dan informasi ketenagakerjaan; pelatihan kerja; penempatan tenaga kerja; perluasan kesempatan kerja; penggunaan tenaga kerja asing; hubungan kerja; perlindungan, pengupahan dan kesejahteraan; hubungan industrial; pemutusan hubungan kerja; pembinaan, pengawasan, penyidikan; hingga ketentuan pidana dan sanksi. Peluang selanjutnya adalah manfaat pengembangan karir bagi manajemen perbankan dapat meningkatkan produktivitas, meningkatkan sikap karyawan terhadap pekerjaannya dan membangun kepuasan kerja yang lebih tinggi, adanya kebijakan mengenai kesetaraan gender, adanya pemahaman mengenai penerapan kesetaraan gender dalam pengembangan karir.

Terakhir adalah ancaman atau hambatan dalam pengembangan karir karyawan bank syariah dan bank konvensional adalah terdapat karyawan lain yang memiliki jenjang pendidikan yang lebih tinggi, terdapat karyawan lain yang merupakan lulusan perguruan tinggi yang memiliki kemampuan untuk berpikir, bekerja dan memiliki daya saing yang lebih baik dan maksimal serta memiliki keinginan untuk menjadi yang lebih kuat untuk selalu menjadi yang terbaik.

Tabel berikut ini adalah penerapankesetaraan gender dalam pelaksanaan pengembangan karir karyawan bank syariah dan bank konvensional dianalisis dengan menggunakan Model SWOT. 
Tabel 1. Penerapan Kesetaraan Gender Dalam Pelaksanaan Pengembangan Karir Karyawan Bank Syariah Dan Bank Konvensional Dianalisis Dengan

Menggunakan Model SWOT

\begin{tabular}{|c|c|c|}
\hline & Peluang : & Ancaman: \\
\hline & $\begin{array}{l}\text { 1. UU No. } 13 \text { tahun } 2003 \\
\text { tentang ketenagakerjaan } \\
\text { 2. Manfaat pengembangan karir } \\
\text { bagi manajemen perbankan } \\
\text { dapat meningkatkan } \\
\text { produktivitas, meningkatkan } \\
\text { sikap karyawan terhadap } \\
\text { pekerjaannya } \\
\text { membangun kepuasan kerja } \\
\text { yang lebih tinggi } \\
\text { 3. Kebijakan } \\
\text { kesetaraan gender mengenai } \\
\text { 4. Memahami tentang } \\
\text { penerapankesetaraan gender } \\
\text { dalam pengembangan karir }\end{array}$ & $\begin{array}{l}\text { 1. Terdapat karyawan lain yang } \\
\text { memiliki jenjang pendidikan } \\
\text { yang lebih tinggi } \\
\text { 2. Terdapat karyawan lain yang } \\
\text { merupakan lulusan perguruan } \\
\text { tinggi yang memiliki } \\
\text { kemampuan untuk berpikir, } \\
\text { bekerja dan memiliki daya } \\
\text { saing yang lebih baik dan } \\
\text { maksimal serta memiliki } \\
\text { keinginan untuk menjadi yang } \\
\text { lebih kuat untuk selalu } \\
\text { menjadi yang terbaik }\end{array}$ \\
\hline $\begin{array}{l}\text { Kekuatan : } \\
\text { 1. Memiliki latar belakang dan } \\
\text { tingkat pendidikan terakhir } \\
\text { yang mendukung } \\
\text { 2. Memenuhi persyaratan untuk } \\
\text { pengembangan karir }\end{array}$ & $\begin{array}{l}\text { Strategi } \\
\text { memanfaatkan } \\
\text { kekuatan } \\
\text { mengisi peluang: } \\
\text { 1. Mengikuti semua tahapan } \\
\text { dalam pengembangan karir } \\
\text { 2. Pengembangan potensi diri } \\
\text { sendiri } \\
\text { 3. Meningkatkan jenjang } \\
\text { pendidikan dan wawasan }\end{array}$ & $\begin{array}{l}\text { Strategi } \\
\text { memanfaatkan } \\
\text { kekuatan } \\
\text { mengatasi } \\
\text { ancaman: } \\
\text { 1. Mengikuti semua proses } \\
\text { pengembangan karir sesuai } \\
\text { dengan masa kerja dan } \\
\text { keahlian } \\
\text { 2. Meningkatkan } \\
\text { pendidikan } \\
\text { 3. Aktif dalam meningkatkan } \\
\text { kemampuan }\end{array}$ \\
\hline $\begin{array}{l}\text { Kelemahan: } \\
\text { 1. Bagi kaum perempuan ada } \\
\text { yang merasa kesulitan } \\
\text { menyakinkan suami untuk } \\
\text { meningkatkan karir di } \\
\text { perbankan } \\
\text { pertimbangan keluarga dan } \\
\text { pekerjaan } \\
\text { 2. Cepat merasa puas }\end{array}$ & $\begin{array}{l}\text { Strategi mengatasi } \\
\text { kelemahan dan } \\
\text { mengisi peluang: } \\
\text { 1. Realisasi dan sosialisasi dari } \\
\text { UU tentang pengembangan } \\
\text { karir } \\
\text { 2. Mewajibkan semua karyawan } \\
\text { untuk mengikuti semua } \\
\text { proses dalam pengembangan } \\
\text { karir ata } \\
\text { 3. Membuat workshop atau } \\
\text { pelatihan tentang kesetaraan } \\
\text { gender dan pentingnya } \\
\text { pengembangan karir. } \\
\text { 4. Menumbuhkan rasa memiliki } \\
\text { karyawan terhadap } \\
\text { perbankan }\end{array}$ & $\begin{array}{l}\text { Strategi } \\
\text { kelemahan } \\
\text { mengatasi } \\
\text { ancaman } \\
\text { 1. Meyakinkan suami bahwa } \\
\text { laki-laki dan perempuan } \\
\text { adalahsama } \\
\text { 2. Bersosialisasi dengan teman } \\
\text { kerja sehingga mampu } \\
\text { menambah semangat untuk } \\
\text { lebih meningkatkan } \\
\text { kemampuan pribadi. } \\
\text { 3. Meningkatkan minat staff } \\
\text { untuk meningkatkan } \\
\text { pengetahuan dan wawasan }\end{array}$ \\
\hline
\end{tabular}


Berdasarkan Model analisis SWOT di atas, maka dapat dirumuskan beberapa strategi pengembangan karir yang dapat dilakukan karyawan bank syariah dan bank konvensional dalam perspektif gender, yaitu:

1. Strategi memanfaatkan kekuatan dan mengisi peluang, yang terdiri dari beberapa strategi, yaitu: a) mengikuti semua tahapan dalam pengembangan karir; b) pengembangan potensi diri sendiri; dan c) peningkatkan jenjang pendidikan dan wawasan.

2. Strategi memanfaatkan kekuatan danmengatasi ancaman, yang terdiri dari beberapa strategi, yaitu: a) mengikuti semua proses pengembangan karir sesuai dengan masa kerja dan keahlian; b) meningkatkan jenjang pendidikan; dan c) aktif dalam meningkatkan kemampuan.

3. Strategi mengatasi kelemahan dan mengisi peluang, yang terdiri dari beberapa strategi yaitu: a) realisasi dan sosialisasi dari UU tentang pengembangan karir; b) mewajibkan semua karyawan untuk mengikuti semua proses dalam pengembangan karir; c) membuat workshop atau pelatihan tentang kesetaraan gender dan pentingnya pengembangan karir; dan d) menumbuhkan rasa memiliki karyawan terhadap perbankan.

4. Strategi mengatasi kelemahan dan mengatasiancaman, yang terdiri dari beberapa strategi, yaitu: a) meyakinkan suami bahwa laki-laki dan perempuan adalah sama; b) bersosialisasi dengan teman kerja sehingga mampu menambah semangat untuk lebih meningkatkan kemampuan pribadi; dan c) meningkatkan minat staffuntuk meningkatkan pengetahuan dan wawasan

\section{Perbedaan Pengembangan Karir Karyawan Bank Syariah dan Bank Konvensional}

Perbedaan pengembangan karir karyawan pada karyawan bank syariah dan karyawan bank konvensional di Kota Pekanbaru ditentukan dengan menggunakan analisis statistik deskriptif ANOVA (One Way Anova).Hasil statistik deskriptif ANOVA, yaitu sebagai berikut : 
Tabel 2. Hasil Deskriptif ANOVA

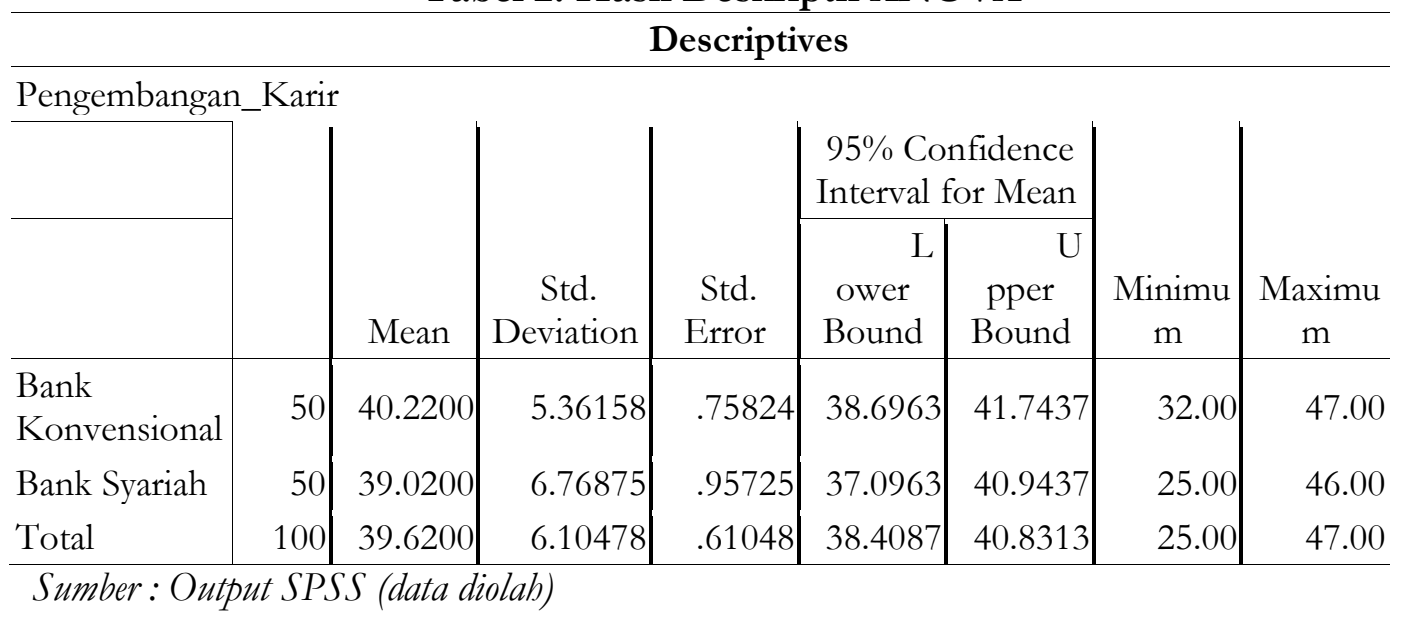

Kemudian untuk melihat perbedaan pengembangan karir karyawan pada karyawan bank syariah dan karyawan bank konvensional di Kota Pekanbaru, terlihat dari hasil uji ANOVA pada Tabel berikut ini :

Tabel 3. Hasil Uji ANOVA

\begin{tabular}{c|c|c}
\hline Variabel & Sig. & Keterangan \\
\hline Pengembangan Karir & 0,328 & Tidak Terdapat Perbedaan \\
\hline \multicolumn{2}{c}{ Sumber: Output SPSS (data diolab) }
\end{tabular}

Berdasarkan uji One Way ANOVA pada tabel 2 diketahui bahwa untuk pengembangan karir karyawan nilai signifikansinya sebesar 0,328 $>0,05$ sehingga dapat disimpulkan bahwa tidak terdapat perbedaan dalam pengembangan karir karyawan pada karyawan bank syariah dan karyawan bank konvensional di Kota Pekanbaru. Berdasarkan hasil uji pada tabel 3 terlihat bahwa pengembangan karir karyawan pada karyawan bank konvensional lebih besar dari pengembangan karir karyawan bank syariah, dilihat dari nilai meankaryawan bank konvensional 40,22 > 39,02 nilai meankaryawan bank syariah.

\section{E. SIMPULAN}

Berdasarkan hasil penelitian dan pembahasan, maka dapat dikemukakan beberapa kesimpulan, yaitu (1) Berdasarkan hasil penelitian diketahui bahwa tidak terdapat kesenjangan gender dalam penerapan pengembangan karir karyawan perbankan di Pekanbaru.Artinya bahwa berbagai indikator dalam pengembangan karir pada penelitian ini tidak membedakan kesempatan untuk memperoleh pengembangan karir baik bagi karyawan laki-laki maupun perempuan. (2) Adapun keseluruhan hasil teknik analisis SWOT berdasarkan hasil penelitian pada Bank Riau Kepri dan Bank Syariah Mandiri mengenai lingkungan eksternal untuk peluang dan hambatan, maupun lingkungan internal 
untuk kekuatan dan kelemahan, sekaligus interaksi antar dimensi-dimensi tersebut dalam memformulasikan strategi bagi penerapan kesetaraan gender dalam pengembangan karir karyawan dalam rangka meningkatkan kesadaran dan pemahaman mengenai pentingnya kesetaraan gender dalam pelaksanaan pengembangan karir. (3) Hasil penelitian menemukan bahwa perbankan telah memberikan kesempatan kepada setiap karyawannya baik laki-laki maupun perempuan untuk mengikuti setiap proses dalam pengembangan karir. (4) Kesetaraan gender dalam pelaksanaan pengembangan karir semakin manfaatnya bagi karyawan di dalam meningkatkan kinerja karyawan perbankan. (5) Berdasarkan uji One $W$ ay ANOVA diketahui bahwa tidak terdapat perbedaan gender dalam hal pengembangan karir antara perbankan konvensional dengan bank syariah. 


\section{DAFTAR REFERENSI}

Astuti Puji. Peluang PNS Perempuan dalam Memperoleh Jabatan Struktural :Studi Kualitas Kesetaraan Gender di Pemerintah Kota Semarang.

Bungin, Burhan, (2006). Metodologi Penelitian Sosial. Surabaya: Airlangga University Press.

Badan Pusat Statistik (BPS), 2015.

Daulay Harmona. B(2006). Buruh Perempuan di Industri Manufaktur Suatu Kajian dan Analisis Gender. Jurnal Wawasan. Edisi Februari 2006/Volume 11, Nomor 3.

Fakih Mansour. (1996). Gender sebagai Alat Analisis Sosial. Jurnal Analisis Sosial. Edisi 4/November. hlm. 7-20. . (2008). Analisis Gender dan Transformasi Sosial. Yogyakarta: InsistPress.

Hubeis, Aida Vitayala S. (2010). Pemberdayaan Perempuan dari Masa ke Masa. Bogor: IPB Press.

Instruksi Presiden. (2000). Instruksi PresidenRepublik Indonesia Nomor 9 Tahun 2000 TentangPengarusutamaan Gender dalam Pembangunan Nasional dan Peraturan Menteri Dalam NegeriNomor 15 tahun 2008 Tentang Pedoman UmumPengarusutamaan Gender di Daerah. Kementrian Pemberdayaan Wanita dan Perlindungan Anak, Jakarta.

Koentjaraningrat. (2007). Metode-Metode Penelitian Masyarakat. Jakarta :Gramedia.

Kuncoro, Mudjarad. (2007). Metode Kuantitatif Teori dan Aplikasi untuk Bisnis dan Ekonomi. Yogjakarta: IPD STIM YKPN,

Marmawi. (2009). Persamaan Gender dalam Pengembangan Diri. Jurnal Visi Ilmu Pendidikan. 1(2): 173-179.

Moleong Lexy.J. (2006). Metodologi Penelitian Kualitatif. Bandung: Remaja Rosdakarya.

Narbuko, Chalil, Abu Achmadi. (2007). Metodologi Penelitian. Jakarta: Bumi Askara.

Sarwono, J. (2009). Statistik Itu Mudah. Yogyakarta: CV Andi Offset.

Sriewijono,dkk. (2006). Cosmopolitan Career Handbook, Vol.2. Jakarta:Cosmopolitan Magazine.

UNFPA, Kantor Meneg Pemberdayaan Perempuan RI, Badan KoordinasiKeluarga Berencana Nasional, 2001. Bahan Pembelajaran PelatihanPengurus Utamaan Gender BidangKesehatan Reproduksi dan Kependudukan.Buku 02. Jakarta. 